\title{
Contextualizing Toni Morrison in Nepalese Classroom of Diversity: A Pedagogic Approach for Students of M.A. in English
}

\author{
Susmita Talukdar ${ }^{1}$ \\ ${ }^{1}$ Padmakanya Multiple Campus, Tribhuvan University, Nepal; Fulbright Visiting Scholar (2018-19), California \\ State University, Fresno, USA \\ Correspondence: Susmita Talukdar, Padmakanya Multiple Campus, Tribhuvan University, Nepal; Fulbright \\ Visiting Scholar (2018-19), California State University, Fresno, USA. E-mail: susmitatalukdar2013@gmail.com
}

Received: March 28, 2019 Accepted: May 8, 2019 Online Published: May 23, 2019

doi:10.5539/ells.v9n2p1 URL: https://doi.org/10.5539/ells.v9n2p1

\begin{abstract}
This article is based on my experience of teaching Nepalese students, who are from different socio-cultural backgrounds. The study proposes a pedagogy through participatory and interactive reading strategy (PAIRS) for Tribhuvan University's 4th Semester Graduate class of English Literature on the course of 'Single Author' (ENG 582), by making them engaged in dialogues, both in oral and written form, in which they will share and exchange their ideas on literary texts of Toni Morrison by investigating on some specific implications of the author's vision on the issues of differences, prevalent in America. The proposed pedagogy is intended for raising students' critical consciousness of the contemporary world's most pertinent issues of identity of minorities, which Nepalese students face in their day to day living experiences. Thus, it is hoped that an individual and collective engagement would be developed in students for dealing with what is both historical and immediate, and global and local. By practicing PAIRS, students would develop self reflection on their biases that would make them critical of their culturally imbedded ideas and that would gradually make them empathetic to differences. The proposed pedagogy is not for demonstrating a teacher's knowledge on the author's works by critical and theoretical tools, but contextualizing the author in Nepalese socio-cultural conditions through the platform of a classroom of diverse thoughts for the students' better understanding of the world, enriched with 'differences'. The study further contributes to new pedagogy of English Studies for Non-western students by widening the field of comparative cultural studies, and thus enhancing the scope of comparative literature.
\end{abstract}

Keywords: Morrison, participatory, interactive, self reflexive, minorities, 'differences'

\section{Introduction}

Nepal is rich in diversity. Its varied multicultural, multireligious and multiethnic properties need wide understanding through a different pedagogical insight and approach so that the uniqueness of each cultural, religious and ethnic community can be recognized, and that would raise collective consciousness for bringing cohesion and unity among diverse groups. My experience of growing up with post colonial education in India culminating with a Ph.D in English on an American author with hyphenated identity, and then joining the academy of Nepal at a time when the country had just got released from the shackles of Panchayati system and gave birth of Democracy, and since then witnessing several changes in the country's socio-political and cultural construct, have made me ponder on how to look at the most burning issues of Nepal not just by remaining constrained with its own history and geography but by going beyond those limitations.

As an academician I am often puzzled by some questions related with my professional responsibilities and the surroundings. What responsibility does a teacher have in making students engaged with their peripheries? What pedagogic strategies should I take for my students who are of different class, caste, religion and communities in teaching the texts of an author, who is from a different cultural place? How to make them take part in sufferings of others by creating a visionary world for them that would broaden their imaginative power? The study is based on how reading and teaching of Toni Morrison, a distinguished American author of African American 'origin', may involve both a teacher and students of Nepal examine critically the issues of minorities that they come to face in their day to day living conditions of life. The study proposes a participatory and interactive reading strategy (PAIR) of Toni Morrison in a Nepalese classroom of students doing M.A. in English Literature, to understand contemporary world's most pertinent issues, related with minorities, (people who are racially, 
ethnically, sexually, and economically marginalized) women, aged people/senior citizens, and children. What social/political causes highlight one group of people from another, and for what purposes? How does one's birth place become the most essential criteria to determine his/her identity?

In general, this study emphasizes how the students of the third world country like Nepal can gain better insights of life by their active involvements of the fictional world of a different society and culture in their approach of positioning themselves as if they are the characters of those texts, and they are going through the events, described in those texts. Though the socio-cultural contexts are different, discrimination, violence, and power politics tell the similar tales of sufferings and survivals of people, whether they are in the center or periphery, in the first world or the third.

In the present socio-political condition of Nepal, we, the academicians need examining the above-mentioned issues most sincerely for developing a better place for our future generation who would be living in a society, free from cruelty and violence, caused by narrow compartmentalization of issues related with identity. Instead of sticking to traditional pedagogic system prevalent in Nepalese education, which is lecturing and depositing information to students for preparing them to get a certificate, I propose how a teacher can use the classroom as a place of excitement by acknowledging everyone's presence, and recognizing the value of each individual's voice, for developing a feeling of community in students. For making a classroom exciting, “... the professor must genuinely value everyone's presence. There must be an ongoing recognition that everyone influences the classroom dynamic, that everyone contributes. These contributors are resources" (hooks, p. 8).

This study focuses on how teaching of Toni Morrison may be useful for critical understanding of Race, Gender, Class, Sexuality, and Community in a Nepalese classroom where the students are from various class, caste, religion, ethnicity, and language speaking zones, and the study is particularly significant for the present M.A. English Program of Tribhuvan University, which has set "Single Author" in its Fourth Semester course of ENGL 582 as one optional study. Toni Morrison's works are particularly crucial for bringing together 'literature' and public culture in a politically conscious relationship.

\section{Background: A Brief Overview of Socio-Cultural Set-Up of Nepal: Toni Morrison in a Nepalese classroom of M.A. in English}

Nepal, the multicultural and multilingual country with its people belonging to different religions, casts, and ethnic communities, has its own history and backdrop. In its own setting therefore, it is a very challenging task for a teacher to introduce students with Toni Morrison whose different cultural and social status demands a different approach for an overall impression of the writer. Moreover, the teacher should be very careful of not providing with information, tinged with his or her own predisposition(s), so that students may develop their understanding freely on their own.

A teacher teaching Toni Morrison in a multicultural, multiethnic, and multireligious classroom of Nepal may face with some problems like making students comprehend the conditions of black people in white America. It is difficult for the students of Nepal to comprehend racial discrimination of white America from their own socio-cultural set-ups. How well the idioms, the nuances and the dynamics of African American community can be recognized as almost their own? The classroom is a place where the histories and experiences of collective memory and social, structural and political inequality are constantly being challenged and redefined. In such case a teacher's responsibility is not making a comparative study between African American and Nepalese society, but rather making students engaged with a different world of African American society in such a way as if it is their own. Historically speaking Nepal was never under Imperialism, but the indirect legacy of colonialism can be seen and felt everywhere in the country, particularly in people's mind set-ups. In this respect Ngugi wa Thiong'o is worth to be pointing out, who said about the effects of Imperialism in global context thus:

Imperialism is total: it has economic, political, military, cultural and psychological consequences to the people of the world today ... but the biggest weapon wielded and actually daily unleashed by the imperialism against the collective defiance [of the oppressed] is the cultural bomb (1986, pp. 2-3).

Colonialism has its effect in Nepal not only on people's habit of fooding and clothing, but also in their mental set-ups. They are influenced by certain ideologies of 'white supremacy' that determine their 'standard' of living and ways of looking around. By 'white supremacy' I do not mean black/white dichotomy on racial grounds but the pernicious effect of colonialism on politically non colonized Asians, particularly, on Nepalese mentality/attitude. Nepalese people have their own history of sufferings and struggles in the power structure dominated by Ranas' dynasty, in its monarchal and Panchayati system. Later with the emergence of Maoist insurgency, and in the present democratic condition, the sufferings of people are still continuing in the strife between 'groups' consisting of pahades and madhesis (in translation people living in hilly, and plain regions, 
respectively), different ethnicities, religions, casts, identities, and several other minorities. In such context it is not much difficult for my students to comprehend Toni Morrison by relating the author and her issues with theirs.

\subsection{Mediating Between Toni Morrison and Reading Public/Students}

Culture plays an important role for interpreting a literary text, which provides an opportunity for readers to explore spaces of convergence of identity and culture between an author and readers. Readers' response to texts that are culturally distant from their own "must construct for themselves an understanding of the imaginary world with which the text deals" (Larsen \& Janos, 1990, pp. 426-427). In general, the scholars of readers' response theory take a reader's active engagement with text for meaning making activities, though the scholars' mode of interpretations differ widely. Some theorists like Rabinowitz (1987) pays attention to the authors' guidelines in interpreting their texts through some literary conventions while still giving the readers an active role. Some theorists assert that texts have little to do with one's interpretation of its meaning; rather it is a reader's own subjective reading that produces the meaning of a text. Bleich's earlier work (1976) emphasizes that literary interpretation largely depends on a reader's personality and or psychology. On the other hand, some theorists, e.g., Rosenblatt considers reading as a negotiation between both the text and the reader, who is engaged in literary interpretation. For her, reading is "... two-way process involving a reader and a text at a particular time, under particular circumstances" (1987, p. 268). Though Rosenblatt has not specifically discussed about a reader's ethnic background, she has emphasized their "myriad experiences (physical personal, social, and cultural) that cause them to perceive their lives in unique ways" (Brooks, Wanda, \& Susan, 2012, p. 77). Rosenblatt says that a text's meaning is shaped on how "... we draw on our reservoir of past experiences with people and the world (culture)" (1987, p. 270). In applying PAIRS in a Nepalese classroom, the culturally situated readers' response theory is proposed for engaging students in dialogue on their present political crisis of identity through the implications of both Toni Morrison's poetics and politics. It is by their active engagement of the author as a cultural mediator that effective dialogues can be created in the classroom to go through the roots of problems.

\subsection{Toni Morrison as a Socially Engaged Writer}

Reading novels is not merely an entertainment, but to be engaged with analytical, critical, and political conversations with cultural practices in everyday living life at its various social engagement. The cultural implication of a text affects a reader in forming the world view, shaping and molding values, beliefs, attitudes that often makes him/her challenge the culture in which s/he is growing up. In "Discourse in the Novel" Bakhtin has said,

Language... becomes 'one's own' only when the speaker populates it with her own intentionality, her own accent, when she appropriates the word, adapting it to her own semantic and expressive intention...the word does not exist in a neutral and impersonal language...but rather it exists in other people's mouths, in other people's contexts, serving other people's intentions (1984, pp. 293-294).

In a similar manner it can be said that the act of novel-making is an act of possession for both the writer and the reader. It is an act in which a certain reordering of the world and its intelligibility is achieved through the very particular process of appropriation and possession of language by writers and readers. Morrison's 'word work' is more than just that; it reveals her status as not only a quintessential story-teller but a public intellectual of the contemporary society. For the author, narrative is a medium of creating and absorbing knowledge. The first sentence of her Nobel Prize acceptance speech begins thus: "Ladies and Gentlemen: Narrative has never been merely an entertainment for me" (Grewal, p. 9). Her fictions, and other writings are at the center of a revolution - a revolution in the fabric of the novel, and in novel-making as a collective activity.

Harold Bloom says that he reads and rereads Toni Morrison "because her imagination, whatever her social purposes, transcends ideology and polemics, and enters again into the literary space occupied only by fantasy and romance of authentic aesthetic dignity" $(2005$, p. 2). But I believe that Morrison's works do not 'transcend ideology', rather the aesthetic sensibilities are propelled in her readers through the author's ideological vision. In the words of Terry Eagleton, a good writing "also means having at one's disposal an ideological perspective which can penetrate to the realities of human experience in a certain situation" (1991, p. 8). For Morrison, the responsibility of a writer is 'response-ability', the capacity of keeping dialogue between the writer and reading public, often mediated by a critic, as Jean-Paul Sartre points out, "The engaged writer knows that words are action. He knows that to reveal is to change, and that one can reveal only by planning to change" $(1949$, p. 14). In Morrison's works this impulse to 'reveal', and therefore to educate and change is constantly present, and that impulse is charged with emotive force. Therefore, it is our responsibilities to free our minds from constrained, 
inherited, unquestioned, and given 'knowledge' produced by academic institutions, dominated by colonial discourse, in order to listen to the authors, who are from different socio-cultural backgrounds on their own terms. However, it is more than inappropriate to define Morrison as 'marginal', not because she has moved to the center of the canon, but because she has managed to move the center, or perhaps it would be more appropriate to say that her multi-faceted and untiring work has helped change a restricted, predominantly white, and male-centered literary world into a multicultural mosaic.

In fact, Toni Morrison is too worthwhile to remain limited to American/Western mainstream. Morrison's works bring together literature, intellectual, and academic environment not only of the first and the second world but also those of the third world. In the 21st century's world of literature and criticism it is not just who speaks and writes, and from what region/context, that matters, but how that speech/writing shapes/reshapes individual and collective experience of people, who are categorically circumscribed by their status of religion, class, caste, ethnicities, sex and similar other tags of identity. On May 8th, 2013 in the occasion of Vanderbilt University's 2013 Senior Class Day, the Chancellor, before awarding Morrison with Nichols Chancellor's Medal, told, "Morrison focuses on common themes that people of all races and ethnicities around the globe can relate to and identify with: hope and dreams, fears of not conforming to ideals, and the value of friendship" (Zeppos, 2013). The rich storytelling and characterization of Morrison's art makes us recognize all those distinct values that connect us with one another in the most basic and profound manner. Morrison's novels are set in past but they pervade contemporary themes, projecting the tensions between "personal and social conceptions of power, success, and fulfillment" (Lister, 2009, p. 75). In an interview with Don Swaim Morrison agreed with his categorization of Beloved as an historical novel, but she pointed out how some of its issues bring controversy in determining the choice between a mother and her self, an issue that remains prevalent in present-day, irrespective of one's race, culture, and or her geographical location. In another interview Morrison also talked about the problem of trying to love oneself and another human being at the same time, which is a serious later twentieth century problem (Silverblatt, 2008).

\section{Literature Review}

Several works have been done on the subject of teaching Toni Morrison. The special Issue on Toni Morrison and the Curriculum of Cultural Studies which is a collection of articles, originated in a symposium entitled "Toni Morrison and the Curriculum", investigates and highlights specific implications of Morrison's works for practice in the classroom as well as for curriculum theorizing in general. Warren Crichlow and Cameron MecCarthy, the editors of this journal assert, "Literature bears traces of alternative approaches to curricular development and pedagogy, and those traces warrant ongoing exploration and analysis" (1995, p. 206). Doyle in her article "'You are Your Own Best Thing': Teaching Toni Morrison's Beloved Using Question-Hypothesis Questions (QHQS)" says,

... we look more closely at classrooms as sites of contestations where knowledge is often politically charged and ignorance is as much an effect of knowledge as it is a void. In studying the use of literature, we must consider how teachers and students deal with their own ambiguous, competing and contradictory interests and relations, and those represented in canonical and counter-canonical works, particularly when these seriously challenge assumptions held about identities represented as culturally different (1995, p. 370).

In Doyle's observation, reading Toni Morrison is not an easy task, as her case study of teaching Beloved demonstrates, which involves a tug of war between a reader/student/teacher and 'knowledge' represented by canonical or minority literature. Searls (1996) in "Race, Schooling, and Double Consciousness: The Politics of Pedagogy in Toni Morrison's Fictions" says that Morrison in her literary and critical writings has emphasized the importance of pedagogy by drawing attention to the facts that knowledge, power, and identities are produced under specific conditions of learning within the academy and outside of it. She asserts that Morrison's fictions teach educators and cultural workers about the deeply political nature of their work and that her fictions offer a critique of and counter-pedagogy to the dominant culture's rules, practices, and pedagogies. In "Approaches to Morrison's Work: Pedagogical" Rose points out that as teachers of Toni Morrison our job is to facilitate active and 'participatory' reading of the author, but we must open our students to Morrison's aesthetics before activating them in 'participatory' reading of the author (2003, p. 23). Timothy Ellen L in Individuation and the Paradox of Love: Toni Morrison's pedagogy of Transformation and Healing has examined Morrison's The Bluest Eye, Beloved, and Paradise to show how Morrison teaches us that love is necessary context of genuine education, and that love is both embracing and liberating (2004). Sangita Rayamajhi says in her essay "Teaching Toni Morrison to a Culturally Diverse Class: Experiences from Bangladesh" that teaching a text of an author from another world is difficult but "... It is greatly satisfying to see how the students captured the sentiments of 
discrimination, isolation, hierarchy, race, class, beauty, women, body and patriarchy" (2005, p. 52). Milligan in the essay "Love, Jazz, and a Sense of the Holy: Conceptualizing the Teacher in Toni Morrison's Beloved" has approached Morrison as a public intellectual with an important insight into education. For Milligan, Morrison is not just an important literary figure, “.. but a philosopher of education whose work constitutes a critical intervention in certain powerful educational discourses" (1993, p. 368). Nandini Bhattacharya's "Postcolonial Agency in Teaching Toni Morrison" is written from her perspective of being a 'diasporic' and 'female academic' of Indian origin, who was assigned to teach Toni Morrison's Song of Solomon in a multicultural classroom of United States (2005).

\section{Justification of the Study}

The above-mentioned books and articles demonstrate how teaching of Toni Morrison has been an important issue for a teacher, either in a multicultural classroom of U.S. or in a South East Asian country like Nepal. My study of teaching Toni Morrison in a Nepalese classroom is different in the sense that it is in contextual understanding of the author's poetics for exploring the problems and possibilities of Nepal's present cultural and political strife involving identity issues. Pedagogic approach of Toni Morrison has never been examined in the context of a Nepalese classroom of diversity. My project examines how students' active engagement of the author can best work for our students' personal queries which would not be alienated from their community as whole. Unlike the channelization of information/knowledge from the centre to the extreme corner of the globe, which is the motto of education policy makers in general, particularly that of Social Science and Humanities, my pedagogic policy defines how to utilize an author's/a literary prophet's vision/philosophy in bringing the cohesion for a community, though it is in a different socio-cultural set-ups from the author's, to find out the problems and possibilities for its people who have been disintegrated by narrow domestic walls of caste, region, religion, and language. The article emphasizes students' participatory and interactive reading strategy (PAIRS) through the fictional world of Morrison for thinking critically of their periphery with minorities, so that they would develop social consciousness to carry responsibilities for their society. In this new pedagogy politics, the educators of Nepal would not just make students interrogate their own ingrained notions of who they are, but would also make them recognize their strength in their 'differences' to add to the cultural diversity of Nepal.

A teacher's job is not just providing information to students for the goal of scoring their pass marks in examination, but also making them engaged in thinking of the surroundings in which they are being reared. As a Toni Morrison scholar my object is utilizing the author in broader zone. In this article a different pedagogic planning is focused on to develop wider vision for the students through their active and participatory engagement of reading Toni Morrison so that they can look at things critically, explore the problems and possibilities. It is by investigating and highlighting specific implications of Morrison's aesthetics on the problems, whether those are concerned with the issues of space, border, identity, or the conflict people face in determining relationship with one another, be it the relationship between spouses, parents and children, or between friends, a different kind of individual and collective engagement would be developed in my students for dealing with what is both historical and immediate, global and local. Through this pedagogic proposal, I do not wish to establish Morrison and her ideology as a readymade solution for the socio-cultural and political crisis of my country, but how to envision a better world for my students so that they would recognize the riches hidden in their history, its diverse cultural resources in their ancient properties, which might bring a new direction to alleviate the causes of their problems/sufferings. Morrison's texts require both teachers' and students' personal involvement with the text and within hegemonic culture that may lead to personal crises, but it ultimately shapes/reshapes one's world view.

Whether a writer is canonical/national or marginal, or a reader is of first, second or third world, we, as both academic and critic, should mediate between a writer and a reading public. What we do is not just important, it is crucial because it shapes the perception of the world as we and others come to 'know' it, and that makes a difference, whether it is acclaiming a popular writer or unfairly criticizing a more complex writer struggling to speak from a different world. The choices we make are not unwarranted; they are often most political, emerging from an ideology that we are not even aware of. If there is one thing that Toni Morrison - an author, a critique, a playwright, a lyricist, a Nobel Prize winner, the recipient of Presidential Medal of Freedom 2012, - has taught us, it is that we are all responsible for those choices as she says, "... as far as the future is concerned, when one writes, as critic or as author, all necks are on the line" (Morrison, 1989).

\section{Discussion on PAIRS in Relation to Morrison's Critical Commentaries}

Students' participatory and interactive reading strategy requires (PAIRS) their active engagement with Morrison's texts, which will make them understand the characters in their situations. Through Morrison's fictive 
world the students would visualize how their religious, regional, ethnic, sexual and class politics have pernicious effect in their community; how people are mentally slaved by the attributes of 'superiority', defined by whiteness. However, such active involvement with Morrison's texts is not an easy task in contemporary technocratic world. Morrison has told in several of her writings about the effect of television culture on our students, who are easily moved by television's simple, formulaic, and linear plot of stories for entertainment. The current networking culture of media is destroying the young generation's imaginative power, which once was generated by the power of 'story-telling' activities. In order to distracting our students from the enthralling effect of net-culture, we, the academicians must open our students to the prophetic vision of writers, whose world of imagination would help them envision their own.

The simple act of considering Morrison's novels in the light of her critical commentary is itself participatory. Morrison as a novelist, theorist, and an educator does not want her readers engage in her writing accepting passively just for the sake of entertainment, rather she wants to lead them experience new and less conventional by being in the company of their own solitary imagination. In "Memory, Creation, and Writing" the author notes, "I want my fiction to urge the reader into active participation in the nonnarrative, nonliterary experience of the text, which makes it difficult for the reader to confine himself to a cool and distant acceptance of data" (Morrison, 1984a, p. 387).

\subsection{PAIRS in Re(discovering) Meanings of Morrison Oeuvre}

In the joint venture of both the students and teacher, through contextualization of Morrison oeuvre in their place and condition, a collaborative pedagogy is proposed in this section with which the students of the third world country like Nepal would be benefitted for understanding the significance of Nepalese culture that is still persistent with them in many different and varied form of communication.

Toni Morrison's artistic attempt lies in reflecting the tradition of African American culture by making conscious use of its art form. She states that she writes in a way that is identifiably black. The author fulfills her responsibilities both as a social and visionary writer by identifying what is valuable of past and what is not. She believes that her works "... must bear witness and identify that which is useful from the past and that which ought to be discarded ... not by avoiding problems and contradictions but by examining them; it should not even attempt to solve social problems, but it should certainly try to clarify them" (Morrison, 1984a, p. 389). This statement is more than a simple caution against narrative didacticism. The teacher can point to the fact that Morrison is not discussing what the storyteller should and should not do, but rather what the story itself should and should not do. Further, Morrison's narrative design does not make any plot that 'solves' its problems. For many students, this concept impels a paradigm shift, enabling them to find new pleasure in certain of Morrison's narrative qualities, such as the lack of clear resolution in her plots, which previously might have caused them readerly discomfort.

The author has always used the novel form to ask questions: What do we understand by the word 'love' or 'paradise'? By what means should we attend to our past? How does one achieve and sustain a sense of self while living in a community? She aims to show us these questions rather than to furnish us with fixed answers through the elaboration of formulaic narratives. Again, the oral tradition sets the standard for her approach. Speaking of those narratives which have been passed down through oral renderings, Morrison stresses the redundancy of Western conceptions of the author as the unitary, totalizing source of all narrative lines, as she says in her interview with Mckay "the fact is that the stories look as though they come from people who are not even authors. No author tells these stories" (Morrison, 1994, p. 152). Like the melodies created by jazz musicians, her stories counter the deterministic and totalizing effect of traditional plot. In "Art of Fiction" Morrison links the ability of learning something out of a mistake to jazz as a mode, “... you have to make something out of a mistake, and if you do it well enough it will take you to another place where you never would have gone had you not made that error. So, you have to be able to risk making that error in performance" (1993, pp. 116-117).

The Black aesthetics on Afro-American art and culture also emphasize art as group collaboration. It must be essentially improvisational because it depends on its relationship to the audience. Students pondering these assertions realize that they must actively participate in the interpretive experience to fulfill the author's intent. They may recognize the strength of communion in practicing dohori (meaning' back and forth'), a popular Nepali folk song, in which a group of male crop-cutters sing and throw question to a group of female singers, who reply to them in equally lyrical improvisation during cutting crops. The students/ readers are given license by the author to respond to the text from their various social positions and histories. The unseen narrator in Jazz says, “...make me, remake me" (Morrison, 1992, p. 129). In that process of making and remaking, both a teacher and students of Toni Morrison are in an emergency of producing new meanings of her texts, responding to the 
needs of social and cultural milieu, we are growing up in. The end of Morrison's Nobel speech appeals for the pedagogic performance (pedagogue, one who leads a child); the griot says, "I trust you now. I trust you now with the bird that is not in your hands because you have truly caught it. Look. How lovely it is, this thing we have done-together" (Peterson, 1997, p. 273). The narratives of love and refusal, lack and plentitude, acceptance and rejection are registered in the collaborative social space of tellers and listeners, writers and readers, teachers and students, where we are entrusted with nothing more powerful than the word/language urging us to make it, remake it.

\subsection{Recognition of the Significance of Nepalese Folk Tales, Myths, and other Forms of Oral Cultures through Morrison's Fictions}

In all of her novels, Morrison aims to involve the reader by recreating the effects of oral transmission. She thinks that the narrative itself must evoke the impression of an oral rendition so that the reader can 'feel' the narrator without 'identifying' that narrator, or hearing him or her knock about (Morrison, 1987, p. 59). One of the strategies that she uses to foster this kind of interaction is the inclusion of a 'choral note' in her novels (p. 60). She uses the novel to engage with a variety of narrative structures and conventions, many of which have been passed on through the oral tradition. The title Tar Baby points the reader to the popular Br'er Rabbit myth deriving from African folk culture, to engage readers in new interpretation of the myth's meanings and associations. In her interview with Thomas Le Clair the author said that myths get forgotten today or they may not have been looked carefully:

I think the myths are misunderstood now because we are not talking to each other the way I was spoken to when I was growing up in a very small town. ... But we don't live where we were born. I had to leave my town. ... There is a certain sense of family I don't have (Morrison, 1994b, p. 122).

The flying myth that the author has used in Song of Solomon is about black people who could fly; the 'flying' can be suggestive of wishful thinking of escape from the torments of slavery for black people. To cite another such example is tar lady myth. In African mythology there is a tar lady; the myth is used in Tar Baby to produce the character of Jadine, a modern girl, who in her search for identity, has succumbed to the dominant commodity culture by coming far away from nurturing and sustaining qualities of black women. In this regard the author further points out to Clair, "For me, the tar baby came to mean the black woman who can hold things together. ... That's what I mean by dusting off the myth, looking closely at it to see what it might conceal" (Morrison. 1994b, p. 122).

The implications of folk tales and myths which students find about African American people would instigate them finding out the significance of their country's folktales, religious practices, rituals, stories which are persistent in the form of art and sculptures, music, dances and many other forms of communication. They would investigate how community cohesiveness can be held through practicing rituals and celebrations of religious festivals, and how liberal attitudes to others' customs would strengthen them by resisting the flood of global (mono) cultural consumerism to be washed away. In general, it is found that the students of English literature in the Third World Countries, are mostly reared in Western literary tradition, and they have little access to the knowledge of Third world Cosmology. In this respect the author says,

In the Third World cosmology as I perceive it, reality is not already constituted by my literary predecessors in Western culture. If my work is to confront a reality unlike that received reality of the West, it must centralize and animate information discredited by the West... discredited not because it is not true or useful or even of some racial value, but because it is information held by discredited people, information dismissed as 'lore' or 'gossip' or 'magic' or 'sentiment' (Morrison, 1984, p. 388).

Thus, informed by the author, the students can approach her texts from non western/African American perspectives which they learn to appreciate in terms of ideology. A Teacher can open discussion on the conflict between ideology and practices with reference to Black people in white America, in relation to Nepalese people who are going through domestic politics of cultural and identity crisis. In their active participation with the texts of Morrison, the students can better understand the complex histories of Breedloves', (The Bluest Eye) the Peaces', (Sula) the Deads', (Song of Solomon), the Streets', the Traces', (Jazz), and similar many others' of Morrison's characters. Instead of being controlled and manipulated, they will enjoy the reading, realizing that they are the chief concerns in the author's creative process, and in this manner their active involvement with the text will help them gain new dimension. They will begin to consider their own responses to the language of the texts. 


\subsection{Proposed Methodology of PAIRS}

In order to involve the students for PAIRS of some texts of Toni Morrison, an inter-group and intra-group dialogue(s) can be initiated so that they can be engaged actively in their interaction with each other, in which they will imagine themselves as if they are entangled in the situations of Morrison's characters. How will they tackle with theirs in their own context? Pecola's tragedy in The Bluest Eye may make them think deeply about the obsession of white beauty that results into catastrophe; they will ponder how the rejection of parental love for a child would prove fatal in their society. The overall impact of such rejection of love for a girl child due to lack of her physical beauty is dangerous not only for the victim but also for the whole community. In both Western and Asian cultures outer good looks are considered to be the reflection of inner beauty. In Asia, furthermore the fairness of the skin is synonymous to being beautiful. In Nepal there is an increasing popularity of Fair and Lovely, a face cream promising to turn dark skin into a fair and lovely one. This and other many such advertisements of consumerism affect a colonized mind believe that to be dark is to be ugly. Many Asians including Nepalese suffer from a low sense of self-esteem due to the internalization of the colonial culture. Such attitude that turns to disowning of the self may lead them to "following an unhealthy path of self-hatred rather than self love" (Hamilton, 1994, p. 116). Besides keeping their dialogues on the textual horrific rape scene of Pecola by her father, students may explore the characters and the circumstances that produced the horrible act.

While reading Sula, the classroom may turn chaotic as on deciding the formulaic definition of a good girl and bad girl, or that of friendship between girls. How such friendship is looked by a patriarchal society? What is the meaning of fidelity in friendship? If a girl does not follow 'rules', assigned by the patriarchal society she is considered a social pariah, as the community of Bottom of Sula considers Sula for her non-conformist behaviour. How a Nepali girl like Sula in all of her nonconformities, would be taken by a Nepalese society?

The teacher may first initiate dialogues on some burning issues after their close reading of the texts like The Bluest Eye, Sula, Song of Solomon, Beloved, Tar Baby in the following way.

- First the teacher will divide the class into 4 groups (namely, A, B, C and D); each of 6 number of students depending on the number of students (Usually a Nepalese Classroom of M.A. in English Literature consists of $25-30$ students).

- $\quad$ Each group would be given 20 minutes for discussing among themselves on a topic they choose (e.g., Beauty; Motherhood; Good Girl/Bad Girl; Motherhood; Freedom; Ancestors etc.).

- Then one representative from each group will read aloud on the basis of their discussion, which will be countered by the members of the similar or other groups.

- The teacher may guide the student, if s/he distracts from the topic, by highlighting the narrative motif or implied intention of the author, but the teacher's instructions by no means should be didactic.

- Next the students of all groups will come to the class by preparing a one page note, that would be exchanged with each other; the exchanges will take place among students, having different topics (e.g., A1 will exchange with suppose $\mathrm{C} 3$, or B2 with D4, and so on, but each will exchange with the one having different topic).

- After the exchanges, they will review their peers' writing carefully, which will enable them to think deeply not just of his/her peer's outlooks, but also will create an opportunity for them to be self reflective to recognize their biases.

- They can prepare their final draft after repeating the process once or twice with their peers (with different peers each time, having the same topic) both in oral and written form of dialogues.

\subsection{Proposed Positive Outcome}

In their critical analysis through PAIRS of some fictions like Sula students may come to recognize a girl's positive revolutionary zeal, though she is considered by textual Bottom community as an evil, a social pariah. They may ponder on how Sula, despite all her non-conformities, contributed to strengthen the bond of love among disparate neighbours in a community, by bringing good changes in it? They may consider some textual reference:

Their (the people of Bottom) conviction of Sula's evil changed them in accountable yet mysterious ways. Once the source of their personal misfortune was identified, they had leave to protect and love one another. They began to cherish their husbands and wives, protect their children, repair their homes and in general band together against the devil in their midst (Morrison, 1998, pp. 117-118).

Further in their analysis of the novel, the students may also engage themselves in discussing how a woman, in 
adopting both Nel's conformist and Sula's nonconformist ideologies, would be useful for a community. Such analysis would enlarge their vision of 'new woman'. The teacher may discuss with the students about the author's vision of 'new woman', who, in search of her self-identity, does not escape from domestic and communal responsibilities, but seeks to bring turmoil in the community's self-complacent attitude of life through her experimental life. Such reading of Sula will create debatable arguments on the definition of 'new woman', in the context of Nepalese culture for further exploration of the subject.

In their readings of the author's four novels-Song of Solomon, Tar Baby, Beloved, and Jazz, they can explore through PAIRS in different ways, how individual characters relate the expanded notion of the ancestor to personal, interpersonal, and communal well-being. Such reading will make them think what roles ancestors have in Nepalese communities? In Nepal a child is reared with the stories, told by a grandma. What effect those stories have for the psychological development of a child that further adds to his/her personality development. While reading Song of Solomon, the students will be engaged in searching for their history that lies hidden in grandmas' tales. Their reading of Beloved will make them engaged with the notion of motherhood, not framed by traditional Nepalese patriarchal ideologies, but within the texture of a mother in her sole demand of her child and its security. While reading Jazz the students may reflect on the significance of ancestor's visionary 'tales', which remain valuable in spite of many changes in the world. Thus, the Nepalese students can be encouraged to investigate their folk tales and folk songs for getting access to their unacknowledged histories and mythologies that contribute to the richness of their folk culture.

In this manner of participatory and interactive reading strategies (PARIS) the students would recognize values deployed in stories, folk songs, and folk dance that record the tales of life, 'lived every day'. Thus, by reading Toni Morrison's texts through PAIRS Nepalese students would be sensitized to form an alternative world view, having their imagination ignited to envision a better future for their community.

\section{Conclusion: Creating Public Consciousness Through Teaching Literature}

The impact of literature is making one critical of assumptions, inherited knowledge(s), values and ideas, which often makes the reader aware of the cultural hegemony that works through a system of manipulation since ages unknown. A joint venture of both an author and readers is to dismantle these assumptions to look into the 'reality' to understand disparity between ideology and practice, and to know how power works to determine 'truth'. An intensive reading of Toni Morrison creates alertness for readers even in a third world country like Nepal to comprehend causes and effects of conflicts, and envision a process for betterment. A good writing triggers our imagination and broadens our sensitivity to the feelings of others.

The imaginative world of Toni Morrison makes a particular demand to readers which forces us to question our ingrained notion of caste, class, ethnicity, religion and gender that in turn makes us acknowledge our implication in the damaging effect of these social ills, and creates a willingness among us to take responsibilities to eradicate these social ills. It is by interpreting and performing within a common and shareable imaginative world of fiction that we can appreciate and nourish our differences, and also find strength in them. The heterogeneous people of Nepal are vibrant with the richness of varieties, and we must be able to recognize the uniqueness of each, not for establishing one's superiority to other but for bringing wider vision of 'unity in diversity' in people. It is by using our classroom as a forum for intellectual discussion of the hegemonic status of identity, defined by hierarchical structure, e.g., upper/lower cast, Hindu/Muslim religion, ethnicity, and 'Pahadi'/'Madhesi' region, (in translation Hilly/Plain), rather than that as a space to deliver our 'knowledge', we can create public awareness of the chasm that slowly destroys a society, unnoticed. Therefore, by contextualizing an author from different world, in this case Toni Morrison, in a Nepalese classroom of English Literature through PAIRS, i.e., participatory and interactive teaching-learning process we may alleviate causes for strives among peoples of differences, and thus construct a better future for our generation. It is by triggering the students' imagination in the visionary world of litterateurs, e.g., of Toni Morrison's, in our "response-ability" tasks, we would help our students develop social awareness of the world and surroundings, which is full of rich varieties. Such awareness will bring empathy for 'differences', which will further be motivated in finding out the uniqueness of those 'differences' for contributing to the enrichment of global diversity. The study further contributes to teaching Western literature to non-western students by widening the field of intercultural and cross-cultural comparative study, and thus promulgating world literature to the remote corner of the world.

\section{References}

Bhakhtin, M. (1984). Discourse in the Novel (Caryl Emerson, Trans.). In H. Michael (Ed.), The Dialogic Imagination (pp. 259-422). Austin, US: Austin university of Texas Press.

Bhattacharya, N. (1995). Postcolonal Agency in Teaching Toni Morrison. Toni Morrison and the Curriculum. 
Cultural Studies (Special issue), 9(2), 227-248. https://doi.org/10.1080/09502389500490351

Bleich, D. (1976). Pedagogical Directions in Subjective Criticism. College English, 37, 454-467. https://doi.org/10.2307/375926

Bloom, H. (Ed.). (2005). Toni Morrison (Introduction, pp.1-5). Philadelphia, USA: Chelsea House Publishers,

Crichlow, W., \& Cameron, M. C. (1995). Toni Morrison and the Curriculum. Cultural Studies (Special issue), 9(2), 205-423. https://doi.org/10.1080/09502389500490331

Doyle, M. A. (1995). 'You are your own best thing': Teaching Toni Morrison's Beloved Using Question-Hypothesis-Question (QHQS). Toni Morrison and the Curriculum. Cultural Studies (Special issue), 9(2), 370-387. https://doi.org/10.1080/09502389500490241

Eagleton, T. (1991). Ideology: An Introduction. U.S.: Verso.

Grewal, G. (1998). Circles of Sorrow, Lines of struggle: The Novels of Toni Morrison. Baton Rouge, USA: Louisiana State UP.

Hamilton, P. C. (1994). Black Nationalism and Toni Morrison: The Journey away from Self-Love. The Bluest Eye. Melus, 19(4), 109-127. https://doi.org/10.2307/468206

Hooks, B. (1994). Teaching to Traansgress: Education as the Practice of Freedom. N.Y. and London: Roultage.

Larsen, S. F., \& Janos, L. (1990). Cultural-historical Knowledge and Personal Experrience in Appreciation of Literature. European Journal of Social Psychology, 20, 425-440. https://doi.org/10.1002/ejsp.2420200505

Lister, R. (2009). Reading Toni Morrison. Santa Barabara, California: Greenwood.

Millian, J. A. (1999). Love, Jazz and a Sense of the Holy: Conceptualizing the Teacher in Toni Morrison's Beloved. Philosophy of Education Archive (pp. 368-376). Retrived from ojs.education.illinois.edu/index/php/issue/19

Morrison, T. (1998). Sula. London: Vintage.

Morrison, T. (1997a). Beloved. London: Vintage.

Morrison, T. (1997b). Nobel Lecture Toni Morrison: Critical and Theoretical Approaches. In J. P. Nancy (Ed.), (pp. 267-273). Baltimore and London: The Johns Hopkins UP.

Morrison, T. (1994a) An Interview with Toni Morrison. (Interviewed by Nellie Mckay). In Danille Taylor Guthrie (Ed.). Conversation with Toni Morrison (pp. 138-155). Jackson: UP of Mississippi.

Morrison, T. (1994b). The Language must not Sweat (Interviewed by Thomas LeClair). In T. G. Danille (Ed.), Conversation with Toni Morrison (pp. 119-128). Jackson: UP of Mississippi. https://doi.org/10.1007/978-1-349-24176-7_8

Morrison, T. (1993a). The Art of Fiction (Interviewed by Elissa Schappell and Claudia Brodsky). Paris Review, (128), 83-115.

Morrison, T. (1993b). On the Backs of Blacks. Time, 1-3.

Morrison, T. (1992a). Song of Solomon. New York: pantheon.

Morrison, T.(1992b). Jazz. London: Picador.

Morrison, T. (1989). Unspeakable Things Unspoken: The Afro-American Presence in American Literature. Michigan Quarterly Review, 28(1), 1-34.

Morrison, T. (1988). Tar Baby. New York: Alfred A. Knopf.

Morrson, T. (1987a). Toni Morrison Interviewed by Don Swaim. Retrieved from http://web.archive.org/web/20080725012746/http://wiredforbooks.org/tonimorrison/

Morrison, T. (1987b). The Site of Memory. In Z. William (Ed.), Inventing the Truth: The Art and Craft of Memoir (pp. 101-124). Boston: Houghton Miffin Company.

Morrison, T. (1984). Memory, Creation, and Writing. Thought (December 59), 385-390. https://doi.org/10.5840/thought198459430

Ngugi, w. T. (1986). Decolonizing the Mind: The Politics of Language in African Literature. London: Heinemann. 
Peterson, N. J. (1997). Toni Morrison: Critical and Theoretical Approaches. Baltimore and London: The Johns Hopkins UP.

Rabinowitz, P. (1987). Before Reading: Narrative Conventions and the politics of Interpretation. Columbus: Ohio U.P.

Rayamajhi, S. (2014). Teaching Toni Morrison to a Culturally Diverse Class. Experience from Bangladesh. In W. S. Kerstin \& G. M. Giulia (Eds.) Living Language Living Memory: Essays on the Works of Toni Morrison (pp. 45-53). Sweeden: Elenders.

Rose, J. A. (2003). Approaches to Morrison's Work: Pedagogical. In A. B. Elizabeth (Ed.), The Toni Morrison Encyclopedia (pp. 23-29). Westport: Greenwood Press.

Rosenblatt, L. (1982). The Literary Transaction: Evocation and Response. Theory into Practice, 21, 268-277. https://doi.org/10.1080/00405848209543018

Sartre, J.-P. (1949). What is Literature? (Bernard Frechtman, Trans.). New York: Philosophical Library.

Searls, S. (1996). Race, Schooling, and Consciousness: The Politics of Pedagogy in Toni Morrison's Fiction. Review of Education, Pedagogy, and Cultural Studies, 18(2), 175-195. https://doi.org/10.1080/1071441960180207

Silverblatt, M. (2008). Things We find in Language. In C. D. Carolyn (Ed.), Toni Morrison: Conversations (pp. 171-177). Jackson: University Press of Mississippi.

Timothy, E. L. (2004). Individuation and the Paradox of Love: Toni Morrison's Pedagogy of Transformation and Healing. Doctoral dissertation. USA: University Press of Washington.

Zeppos, N. (Novelist Morrison tells grads to embrace interconnectedness.) (2013, May 9). Senior Day (Video File). Retrieved from https:// news.Vanderbilt.edu/2013/05/09/toni-morrison-address/

\section{Copyrights}

Copyright for this article is retained by the author, with first publication rights granted to the journal.

This is an open-access article distributed under the terms and conditions of the Creative Commons Attribution license (http://creativecommons.org/licenses/by/4.0/). 